\title{
KUALITAS PELAYANAN PENCATATAN MASJID BERBASIS TEKNOLOGI INFORMASI PADA KANTOR URUSAN AGAMA KECAMATAN PAHANDUT KOTA PALANGKA RAYA
}

\section{Quality Of Mosque Registration Services Based On Information Technology In Religious Affairs Office Pahandut Sub-District The Palangka Raya City}

\section{Nicodemus* \\ Budy Fitri Effendi}

Universitas Muhammadiyah Palangkaraya, Palangka Raya, Central Kalimantan, Indonesia

email: nicodemus.r.toun@gmail.com

Kata Kunci:

Kualitas Pelayanan

Pencatatan

Teknologi Informasi

\section{Keywords:}

Service Quality

Registration

Information Technology

\begin{abstract}
Abstrak
Penelitian ini membahas sejauhmana kualitas pelayanan pencatatan Masjid berbasis teknologi informasi pada KUA Kecamatan Pahandut Kota Palangka Raya. Secara lebih spesifik tujuan dari penelitian ini adalah I) untuk mengetahui pelaksanaan pelayanan publik dalam Pencatatan Masjid Berbasis Teknologi Informasi di KUA Kecamatan Pahandut Kota Palangka Raya 2) untuk mendeskripsikan dan menganalisa kualitas pelayanan publik dalam Pencatatan Masjid Berbasis Teknologi Informasi di KUA Kecamatan Pahandut Kota Palangka Raya 3) untuk mengetahui hambatan-hambatan apa saja yang menghalangi penerapan Pelayanan Masjid berbasis Teknologi Informasi di KUA Kecamatan Pahandut Kota Palangka Raya. Penelitian ini menggunakan pendekatan Kualitatif Deskriptif.

Penelitian kualitatif adalah prosedur penelitian yang menghasilkan data deskriptif berupa kata-kata tertulis atau lisan dari orang-orang dan perilaku yang dapat diamati. Bersifat deskriptif yaitu dalam kajian ini, analisis terhadap informasi tidak keluar dari bahan yang diteliti yaitu bahan-bahan hasil lapangan seperti hasil-hasil wawancara, observasi maupun dokumentasi secara mendalam agar mampu mendapat data yang valid.

Hasil penelitian menunjukkan bahwa : I) Pelaksanaan Pelayanan Pencatatan Masjid berbasis Teknologi Informasi di KUA Kecamatan Pahandut Kota Palangka Raya tidak mengalami permasalahan yang signifikan 2) dilihat dari segi bukti fisik, kehandalan, daya tanggap, jaminan dan empati, KUA Kecamatan Pahandut Kota Palangka Raya memiliki keragaman permasalahanpermasalahan di dalamnya 3) ada pun hambatan-hambatan dalam pelaksanaan pelayanan pencatatan Masjid berbasis teknologi informasi antara lain dari aspek sumber daya aparatur, kesadaran masyarakat serta sarana dan prasarana.
\end{abstract}

\begin{abstract}
The research discusses the quality of the mosque's recording services based on the information technology in the district of Pahandut, Palangka Raya. More specifically the purpose of this research is I) to know the implementation of public services in the registration of mosque-based information technology in the district of the KUA Pahandut City Palangka Raya 2) to describe and analyze the quality of Public service in the mosque's registration of information technology at the KUA district of Pahandut City Palangka Raya 3) to know any obstacles that preclude the application of the mosque service based on information technology in KUA District The city of Palangka Raya. This research uses qualitative descriptive approaches.
\end{abstract}

Qualitative research is a research procedure that generates descriptive data of written or spoken words from people and behaviors that can be observed. Being descriptive in this study, analysis of information is not out of the materials that are researched that is the material of the field such as the results of interviews, observation or documentation indepth to be able to get valid data.

The results of the study showed that: I) the implementation of information technologybased mosque in KUA subdistrict of Pahandut City Palangka Raya does not suffer significant problems 2) seen in terms of physical evidence, reliability, responsiveness, assurance and empathy, KUA district of Pahandut City Palangka Raya has a diversity of problems in it 3) there are also barriers in the implementation of the registration services mosque-based information technology among others from the aspect of resources Public awareness and facilities and infrastructure. 


\section{PENDAHULUAN}

Pelayanan publik merupakan suatu usaha yang dilakukan kelompok atau seseorang birokrasi untuk memberikan bantuan kepada masyarakat dalamrangka mencapai suatu tujuan tertentu. Salah satu dari pelaksanaan pelayanan publik yaitu administrasi pencatatan rumah ibadah yang berada di suatu wilayah pemerintahan. Administrasi pencatatan rumah ibadah adalah rangkaian kegiatan penataan dan penertiban dalam penertiban dokumen dan data rumah ibadah melalui pendaftaran rumah ibadah, pencatatan rumah ibadah, pengelolaan informasi administrasi rumah ibadah serta pendayagunaan hasilnya untuk pelayanan publik dan pembangunan sektor lain.

Sasaran strategis dari Kementerian Agama sebagai perpanjangan tangan Pemerintah, dalam hal ini dibidangi oleh Bidang Bimbingan Masyarakat Islam (Bimas Islam) adalah mengoptimalkan pelayanan kehidupan beragama masyarakat Islam, seperti pelayanan perkawinan, ketahanan keluarga sakinah, produk halal, pemberdayaan masjid, serta pembinaan syariah dan hisab dan rukyat. Pelayanan kehidupan beragama masyarakat Islam adalah ketersediaan daya dukung pelaksanaan seluruh kegiatan keagamaan Islam, baik yang bersifat ibadah maupun mu'amalah dengan merujuk pada norma, ajaran, dan praktik-praktik keagamaan Islam dimasyarakat.

Program pemberdayaan masjid dan mushalla telah dilakukan oleh Bimas Islam agar rumah ibadah mampu menjadi unit layanan keagamaan umat Islam. Masjidmasjid besar di Indonesia ke depannya diharapkan memenuhi standar pelayanan bagi masyarakat Islam, khususnya untuk pelayanan ibadah dan syiar Islam (pelayanan ilmu Islam dan konseling), seperti adanya tempat wudhu yang memadai, alat shalat, Al-Quran, perpustakaan Masjid, takmir Masjid, Majelis taklim, dan kegiatan-kegiatan syiar Islam lainnya. Untuk tujuan ini, Bimas Islam telah memberikan bantuan kepada masjid dan mushalla di seluruh Indonesia, termasuk pemberian sarana-prasarana beserta kitab suci Alquran dan pustaka Islami. Disamping 4 itu telah dilakukan berbagai upaya peningkatkan kapasitas pengelola masjid dan mushalla untuk meningkatkan kapasitas rumah ibadah sebagai pusat pemberdayaan umat dan pengembangan peradaban, termasuk juga pencatatan Masjid atau Musholla berbasis Teknologi Informasi yang dilakukan oleh Bimas Islam melalui KUA-KUA di Kecamatan, tidak terkecuali oleh KUA Kecamatan Pahandut Kotamadya Palangka Raya Provinsi Kalimantan Tengah.

Pelayanan pencatatan rumah ibadah, khususnya umat Islam, berbasis Teknologi Informasi dinamakan dengan Sistem Informasi Masjid atau sering disingkat menjadi SIMAS. Teknologi Informasi pada desain dan dikembangkan berdasarkan kebutuhan riil terkini, dengan sistem yang mudah diakses dan dioperasikan oleh para operator yang ditugaskan, untuk membantu dalam penghimpunan data dan sumber-sumber penting terkait dengan ruang lingkup masjid dan mushalla dengan berbagai kearifan dan keunikannya. Dengan SIMAS ini diharapkan akan terwujud single data rumah ibadah muslim secara nasional yang akurat dan akuntabel.

Kantor Urusan Agama (KUA) Kecamatan tidak lepas sebagai kepanjangan tangan dari pemerintah, dalam memprakarsai pelayanan pencatatan Masjid atau Mushola berbasis Teknologi Informasi melalui aplikasi SIMAS ini, tidak terkecuali KUA Kecamatan Pahandut Kota Palangka Raya Provinsi Kalimantan Tengah. Namun demikian, pelayanan pencatatan Masjid atau Mushola berbasisTeknologi Informasi bukanlah satu hal yang mudah untuk diterapkan, disebabkan selama ini metode tradisional dalam pelayanan ini sudah menjadi kebiasaan yang sangat sulit untuk dirubah. Terlihat pada data Badan Pusat Statistik Kota Palangka Raya, pada tahun 2017 terdapat jumlah rumah ibadah umat Islam yang ada di Kecamatan Pahandut berjumlah 172 buah, dengan rincian 80 buah Masjid 5 dan 92 buah 
Musholla atau langgar. Sedangkan data yang termuat dalam aplikasi SIMAS Kementerian Agama Kota Palangka Raya, Kecamatan Pahandut memiliki rumah Ibadah Muslim berjumlah 176 buah, dengan rincian 62 buah Masjid dan II4 buah Musholla.

Berdasarkan hal inilah, penulis merasa tertarik mengangkat permasalahan ini dalam bentuk penelitian Imiah dengan judul "Kualitas Pencatatan Masjid Berbasis Teknologi Informasi Pada Kua Kecamatan Pahandut Kota Palangka Raya”.

\section{METODOLOGI}

Kajian penelitian ini bersifat desktiptif dan deduktif. Bersifat deskriptif yaitu dalam kajian ini, analisis terhadap informasi tidak keluar dari bahan yang diteliti yaitu bahan-bahan hasil lapangan seperti hasil-hasil wawancara, observasi maupun dokumentasi secara mendalam agar mampu mendapat data yang valid. Berpola deduktif karena berdasarkan teori atau konsep yang bersifat umum diaplikasikan untuk menjelaskan seperangkat informasi kajian. Pola ini menjabarkan permasalahan yang kompleks serta membutuhkan pengertian makna secara mendalam, sehingga perlu dilakukan wawancara, observasi maupun dokumentasi secara mendalam agar mampu mendapat data yang valid. Dalam penelitian ini, wawancara dan observasi dilakukan di Kantor Urusan Agama Kecamatan Pahandut Kota Palangka Raya Provinsi Kalimantan Tengah.

\section{HASIL DAN PEMBAHASAN}

Secara keseluruhan, KUA Kecamatan Pahandut Kota Palangka Raya telah melaksanakan tugasnya sebagai Lembaga kepanjangan tangan pemerintah dalam menangani pencatatan Masjid berbasis $\mathrm{TI}$ di tingkat Kecamatan.kepala KUA Kecamatan Pahandut berpendapat bahwa dalam memberikan pelayanan pencatatan Masjid melalui aplikasi SIMAS, telah berusaha dengan memberikan pelayanan maksimal kepada masyarakat di lingkungan kecamatannya. Namun demikian, bukan berarti tidak ada kekurangan dalam memberikan pelayanan pencatatan Masjid melalui media $\mathrm{TI}$.

Dalam procedural, pelaksanaan pelayanan pencatatan Masjid berbasis TI, yakni SIMAS memudahkan si pendaftar rumah ibadah, khususnya Masjid maupun Musholla dalam mendaftarkan Masjid atau Mushollanya, tetapi beberapa factor seperti kekurangan administrasi yang diserahkan, penjelasan yang kurang diterima oleh si pendaftar Masjid atau Musholla terhadap pelayanan pencatatan Masjid berbasis SIMAS, dan pelaksanaan penginputan Masjid ke dalam aplikasi SIMAS merupakan persoalan yang menjadikan pelayanan pencatatan Masjid berbasis SIMAS tersebut menjadi sedikit bermasalah.

I. Deskripsi dan Analisa

Pelayanan publik saat ini menjadi bagian kebutuhan setiap masyarakat. Setiap birokrasi publik perlu berupaya untuk memberikan kualitas pelayanan yang terbaik kepada masyarakat pengguna layanan. Pelayanan publik seperti Pelayanan Pencatatan Masjid pada KUA Kecamatan Pahandut Kota Palangka Raya, saat ini dirasakan semakin perlu untuk dibenahi dan ditingkatkan, terlebih dalam era digital seperti ini. Upaya untuk meningkatkan kualitas pelayanan publik yang lebih baik merupakan suatu keharusan yang harus segera dilakukan untuk menciptakan pelayanan lebih efisien, efektif dan sesuai dengan kebutuhan dan aspirasi masyarakat. Kualitas pelayanan publik bidang Pelayanan Pencatatan Masjid berbasis Teknologi Informasi dapat dilihat dari beberapa aspek, yaitu:

a. Aspek bukti Fisik (tangible)

Dalam mewujudkan pelayanan publik yang berkualitas perlu dilakukan perubahan dan 
perbaikan yang mengarah pada kepuasan masyarakat. Salah satu aspek yang harus diperbaiki dalam meningkatkan kualitas pelayanan yaitu masalah fasilitas layanan. Peranan sarana prasarana pelayanan sangat penting dan salah satu yang sangat berpengaruh terhadap peningkatan kualitas pelayanan publik karena dengan adanya sarana prasarana pelayanan yang memadai dapat membuat pelayanan pada masyarakat dapat lebih memberikan kenyamanan dan kepuasan selama berada di ruangan pelayanan.

Dalam aspek bukti fisik (tangible), KUA Kecamatan Pahandut Kota Palangka Raya memiliki luas ruang untuk kapasitas jumlah petugas pelayanan 4-6 orang. Ruangan pelayanan terdapat meja pelayanan, meja kerja, Personal Komputer dan kursi panjang yang diperuntukan bagi masyarakat yang menunggu pelayanan. Mengenai kelengkapan peralatan serta sarana internet belum maksimal khususnya personal komputer ataupun alat pengakses internet lainnya. Fasilitas penunjang seperti genset maupun alat kantor lainnya belum dimiliki oleh KUA Kecamatan Pahandut Kota Palangka Raya.

b. Aspek keandalan (realiability)

Semakin tingginya kebutuhan masyarakat akan pelayanan ini perlu diimbangi dengan pelayanan yang maksimal dan cepat yang menuntut aparatur untuk cekatan dalam bekerja. Keandalan merupakan kemampuan memberikan pelayanan yang dijanjikan dengan segera, akurat dan memuaskan, seperti ketepatan waktu, kecepatan dan kecermatan dalam penyelesaiaan pelayanan. Keandalan disini merupakan sejauh mana para aparatur dapat secara cepat, tepat dan kecermatan dalam setiap pemberian pelayanan kepada masyarakat, khususnya dalam pelayanan pencatatan Masjid berbasis teknologi informasi. Dalam memberikan pelayanan kepada masyarakat kehandalan dan profesionalisme dalam memberikan suatu jasa dengan segera, akurat dan memuaskan sangat diperlukan agar terciptanya kepuasan dalam diri pelanggan.

Hasil penelitian terungkap bahwa masyarakat pada Kecamatan Pahandut merasa puas dengan pelayanan KUA Kecamatan Pahandut Kota Palangka Raya yang di berikan para aparatur KUA dalam aspek reliability (kehandalan) mengenai kehandalan dalam menangani setiap keluhan masyarakat, handal dalam segi waktu dan ketepatan proses pelayanan, seperti yang disampaikan bapak B "Prosedur pendaftaran Masjid pada KUA Kecamatan Pahandut Kota Palangka Raya cukup mudah, saya cuma nyerahin syaratsyarat ke petugasnya dan mengikuti instruksi yang diberikan petugas dalam pendaftaran pencatatan Masjid, sehingga pelayanannya jadi cepat”.

c. Aspek daya tanggap (responsiveness)

Responsivitas pegawai, utamanya Kepala KUA Kecamatan Pahandut Kota Palangka Rayabeserta para staffnya sangat diperlukan dalam pelayanan publik karena hal ini menjadi bukti serta tindakan nyata yang dilakukan organisasi dalam menjawab serta mengenali kebutuhan dan aspirasi dari masyarakat. Daya tanggap disini dapat berarti respon atau kesigapan petugas dalam membantu masyarakat yang membutuhkan pelayanan. Hal ini ternyata respon/daya tanggap yang diberikan oleh petugas KUA Kecamatan Pahandut Kota Palangka Raya sesuai dengan apa yang dibutuhkan oleh masyarakat. 
d. Aspek jaminan (Assurance)

KUA Kecamatan Pahandut Kota Palangka Raya sebagai kantor yang berwenang menangani masalah pencatatan Masjid secara online, khususnya warga kecamatan Pahandut. Banyaknya masyarakat yang datang sudah seharusnya mendapatkan kenyamanan selama pelayanan yaitu dengan cara memberikan rasa aman bagi masyarakat selama pelayanan, baik dilingkungan kantor maupun di luar kantor. Oleh sebab itu, perlu adanya suatu perbaikan pelayanan untuk memberikan rasa aman bagi masyarakat selama pelayanan.

Selain dari jaminan keamananan lingkungan pelayanan ada yang tidak kalah penting yaitu dengan adanya jaminan yang pasti terhadap pemohon administrasi pelayanan pencatatan Masjid dengan kemampuan yang diberikan pihak instansi, sehingga mereka merasa puas. Dalam hal ini kompetensi petugas pemberi pelayanan publik harus dengan tepat berdasarkan pengetahuan, keahlian, keterampilan, sikap dan perilaku yang dibutuhkan. Petugas pelayanan di KUA Kecamatan Pahandut Kota Palangka Rayatelah berupaya maksimal untuk melaksanakan tugas dengan baik proses pelayanan berlansung. Apabila ada keluhan dari masyarakat pihak KUA Kecamatan Pahandut Kota Palangka Raya setempat akan segera menindak lanjuti.

Para pegawai KUA Kecamatan Pahandut Kota Palangka Rayatelah berupaya maksimal untuk melaksanakan tugas dengan baik selama proses pelayanan berlangsung. Apabila ada keluhan dari masyarakat maka para petugas KUA Kecamatan Pahandut Kota Palangka Rayaakan segera menindak lanjuti. $\mathrm{Hal}$ tersebut sesuai dalam Keputusan Menteri Pendayagunaan Aparatur Negara No.
63/KEP/M.PAN/7/2003 dan UU No. 25 tentang Standar Pelayanan yang salah satunya Kompetensi petugas pemberi pelayanan harus ditetapkan dengan tepat berdasarkan pengetahuan, keahlian, keterampilan, sikap, dan perilaku yang dibutuhkan.

e. Aspek empati (empaty)

Empati merupakan rasa peduli untuk memberikan perhatian kepada masyarakat terhadap kebutuhan yang sedang membutuhkan pelayanan. Sebagai instansi publik yang memberikan pelayanan dituntut untuk selalu siap dalam membantu masyarakat yang membutuhkan pelayanan. Kepedulian pegawai untuk selalu mengutamakan kebutuhan masyarakat akan mendukung terciptanya kualitas pelayan publik.

Dari hasil wawancara dengan masyarakat dapat diketahui masalah kesediaan petugas dalam melayani masyarakat sudah baik dengan banyaknya tanggapan masyarakat yang menyatakan cukup baik. Pemberian pelayanan kesediaan aparat dalam memberikan informasi merupakan hal yang perlu mendapat perhatian. Kesediaan pegawai dalam menberikan informasi terhadap masyarakat yang membutuhkan pelayanan akan dapat memperbaiki cara pelayanan di mata masyarakat. Sehingga dalam menciptakan pelayanan prima masyarakat perlu didukung dengan adanya pegawai yang berempati dalam membantu kebutuhan masyarakat yang butuh informasi.

2. Hambatan-hambatan

Dalam melaksanakan tugasnya sebagai pelayanan umum, KUA Kecamatan Pahandut Kota Palangka Raya menghadapi beberapa permasalahan dalam proses penyelenggaraan pelayanan publiknya, 
khususnya dalam pelayanan pencatatan Masjid berbasis Teknologi Informasi yang antara lain sebagai berikut :

\section{a. Sumber Daya Aparatur}

Memberikan pelayanan yang maksimal kepada masyarakat sangat dibutuhkan aparatur pemerintah yang memadai. Jumlah operator yang ada rata-rata pada KUA Kecamatan Pahandut Kota Palangka Raya 2 orang, dan hal ini menyebabkan kekurangan tenaga keahlian teknis dalam menjalan aplikasi SIMAS tersebut.

b. Kesadaran Masyarakat

Salah satu faktor yang turut mempengaruhi pelaksanaan tugas pelayanan pemerintah di KUA Kecamatan Pahandut Kota Palangka Rayaadalah faktor kesadaran masyarakat. Kesadaran masyarakat dimaksudkan ialah kesadaran masyarakat untuk mengetahui sekarang dalam pencatatan Masjid dapat dilihat pada jaringan internet. $\mathrm{Hal}$ ini memungkinkan masyarakat tidak perlu lagi hanya datang ke KUA Kecamatan hanya menanyakan berbagai macam persyaratan untuk pendaftaran pelayanan pencatatan Masjid di KUA di maksud.

Mempersiapkan segala yang menjadi persyaratan untuk melakukan suatu urusan pelayanan di kantor Kecamatan, relasi antara aparat pemerintah dengan masyarakat memang harus saling mendukung agar dapat mencapai tujuan yang di harapkan, baik itu dari pihak masyarakat maupun dari aparat pemerintah sendiri.

c. Sarana dan Prasarana

Keadaan sarana dan prasarana penyelenggarakan pelayanan publik yang belum terpenuhi secara lancar bagi kepentingan urusan pelayanan. Belum terpenuhinya tempat pelayanan dengan sarana ruang tunggu/tamu serta belum ditunjang dengan fasilitas-fasilitas yang dapat menciptakan suasana nyaman bagi pemohon pelayanan. Belum tersedianya alat atau server internet yang memadai untuk kapasitas suatu kantor sehingga dalam pelayanan pencatatan Masjid berbasis Teknologi Informasi terkendala dalam melaksanakannya. Selain itu, beberapa KUA Kecamatan Pahandut Kota Palangka Rayabelum memiliki genset apabila di saat pelayanan berlangsung kemudian ada gangguan dalam hal masalah listrik, maka pelayanan harus dihentikan disebabkan belum adanya genset tersebut.

\section{KESIMPULAN}

Pelaksanaan Pelayanan Pencatatan Masjid berbasis teknologi informasi di KUA Kecamatan Pahandut Kota Palangka Raya termasuk dalam kategori baik dan tidak mengalami masalah yang serius dalam pelaksanaannya. Hal ini dapat dilihat dari segi bukti fisik (tangible), kehandalan (reliability), daya tanggap (responsiveness), jaminan (Assurance), dan empati (empathy).

Adapun mengenai kendala atau hambatan dalam meningkatkan kualitas pelayanan publik, khususnya pelayanan pencatatan Masjid berbasis Teknologi Informasi pada KUA Kecamatan Pahandut Kota Palangka Raya Melaksanakan tugasnya sebagai pelayanan umum, menghadapi beberapa permasalahan dalam proses penyelenggaraan pelayanan publiknya, yang antara lain sebagai berikut:

a. Sumber daya aparatur yang masih belum maksimal, dilihat dari jumlah operator yaang hanya berjumlah 2 orang dan hal ini nyebakan kekurangan tenaga keahlian teknis dalam menjalankan aplikasi SIMAS tersebut. 
b. Kesadaran masaryarakat dalam mengetahui tata cara pencatatan mesjid dan mempersiapan segala yang menjadi persyaratan untuk pendaftaran pencatatan mesjid masih rendah.

c. Sarana dan parasarana penyelenggaran pelayanan publik belum terpenuhi secara keseluruhan. $\mathrm{Hal}$ ini karena belum tersediannya alat atau server interet yang memadai untuk kapasitas suatu katnor sehingga dalam pelayanan pencatatan masjid yang berbasis IT terkendala dalam pelaksanaannya.

\section{REFERENSI}

Fahlefi, Zul. Februari. 2004. Penerapan Teknologi Informasi Bagi Pelaksanaan Pelayanan Publik. ejournal administrative reform. Vol. 2.

Harcahyani, Grestiyaning. 2010. Analisis Pengaruh Kualitas Pelayanan Terhadap Kepuasan Pasien Yang Dimoderasi Oleh Variabel Nilai (Studi Pada Pasien Instalasi Rawat Jalan RSUD Kota Yogyakarta). Tesis. Surabaya: Universitas Pembangunan Nasional "Veteran” JawaTimur.

Hardiyansyah. 20II. Kualitas Pelayanan Publik. Yogyakarta : Gava Media

Holle, Erick S. 20I I. Pelayanan Publik Melalui Electronic Government: Upaya Meminimalisir Praktek Maladministrasi Dalam Meningkatkan Public Service. Jurnalsasi, Vol. 17, No. 3, JuliSeptember.

Indrajit, R. E.2002. Electronic Government "Strategi Pembangunan dan Pengembangan Sistem Pelayanan Publik Berbasis Teknologi Digital". Yogyakarta: Andi.

Lukman, Sampara. 2000. Manajemen Kualitas Pelayanan. Jakarta: STIA LAN Press.

Moenir, H.A.S. 2002. Manajemen Pelayanan Umum di Indonesia. Jakarta: Bumi Aksara.

Ratminto \& Atik Septi Winarsih. 2007. Manajemen Pelayanan. Yogyakarta : Pustaka Pelajar.
Sinambela, Lijan Poltak. 2010. Reformasi Pelayanan Publik. Jakarta: Bumi Aksara.

Tangkilisan, Nogi Hessel. 2005. Manajemen Publik. PT. Gramedia Widiasarana Indonesia : Jakarta. 